\title{
Wspieranie rozwoju kreatywności dziecka jako element praktyki logopedycznej. O możliwych związkach logopedii z pedagogiką twórczości
}

\begin{abstract}
Marta Galewska-Kustra, Wspieranie rozwoju kreatywności dziecka jako element praktyki logopedycznej. O możliwych związach logopedii z pedagogika twórczości [Supporting children's creativity as a component of a speech therapy practice. On potential links between logopedics and pedagogy of creativity]. Interdyscyplinarne Konteksty Pedagogiki Specjalnej, nr 14, Poznań 2016. Pp. 53-71. Adam Mickiewicz University Press. ISSN 2300-391X
\end{abstract}

Logopedics and pedagogy of creativity are the disciplines whose areas of research interests are different. Some may say that they have nothing in common. The main tasks and goals undertaken by the speech therapists are different from those by creativity educators. Speech therapists' work is directly connected with prevention and therapy of speech disorders. Creativity educator supports, enhances and develops creative abilities, creative attitude of children, adolescents and adults. However, the goals of creativity education may become a part of the speech therapy practice. This article is an attempt to illustrate the possible relations between pedagogy of creativity and logopedics, and to show the practical ways in which the practice of speech therapy may become an opportunity to develop children's creativity.

KEY WORDS: child creativity, creative abilities, creative speech theraphy, logopedics, pedagogy of creativity 


\section{Logopedia i pedagogika twórczości - w poszukiwaniu wspólnych celów}

Przedmiot badań i zainteresowań logopedii, jej zasadnicze cele jako dyscypliny nauki, były i są nadal rozważane przez teoretyków i praktyków. Różnorodność ustaleń w tym zakresie wynika przede wszystkim ze złożoności problematyki, którą logopedia i logopedzi się zajmują. Złożoność ta powoduje trudność w jednoznacznym określaniu logopedii jako samodzielnej dyscypliny naukowej, przyczynia się do wskazywania interdyscyplinarności jako jej cechy immanentnej. Prowadząc rozważania w tym temacie, polscy logopedzi najczęściej odwołują się do stanowiska Leona Kaczmarka, Ireny Styczek czy Stanisława Grabiasa. Ustalenia wspomnianych autorów różnią się od siebie, wywołując jednocześnie daleko idące konsekwencje dla określania zainteresowań badawczych i działań praktycznych logopedy. Są one znane wszystkim logopedom, a zatem dość przypomnieć, że według Stanisława Grabiasa przedmiotem badań logopedii jest nie tyle mowa czy komunikacja językowa rozumiana szeroko, co występujące $w$ ich zakresie zaburzenia1. Z kolei Leon Kaczmarek przywoływany jest często jako przedstawiciel poglądu, iż przedmiot badań logopedii rysuje się znacznie szerzej i obejmuje wszelkie zagadnienia dotyczące mowy i procesu porozumiewania się 2 . Zdaniem Grażyny Jastrzębowskiej przedmiot badań logopedii należy rozumieć odmiennie od jej przedmiotu zainteresowań. To właśnie ten ostatni traktowany winien być szeroko. $W$ jego zakres wchodzą te aspekty związane $\mathrm{z}$ mową, procesem komunikowania się, które stanowią przedmiot badań innych, współpracujących z logopedią dyscyplin naukowych ${ }^{3}$.

1S. Grabias, Mowa i jej zaburzenia, „Audiofonologia” 1997, t. 10.

2 L. Kaczmarek, Model opieki logopedycznej w Polsce, Gdański Związek Logopedów, Gdańsk 1991.

${ }^{3}$ G. Jastrzębowska, Podstawowe problemy logopedii, [w:] Logopedia. Pytania i odpowiedzi. Tom 1: Interdyscyplinarne podstawy logopedii, red. T. Gałkowski, G. Jastrzębowska, Wydawnictwo Uniwersytetu Opolskiego, Opole 2003. 
Dla oznaczenia możliwości włączania celów pedagogiki twórczości do praktyki logopedycznej pomocne zdaje się być odwołanie do przedstawianych ogólnie przez Jastrzębowską specjalności logopedii. Powołując się na ustalenia Leona Kaczmarka i Ireny Styczek, autorka dzieli logopedię na teoretyczną i stosowaną, w ramach tej ostatniej wyodrębniając logopedię ogólną i specjalną. Logopedia ogólna zawiera w sobie szereg działań praktycznych, które wpisać można w dwa obszary: logopedii wychowawczej i artystycznej. Zaś logopedia specjalna realizowana jest w ramach logopedii korekcyjnej i surdologopedii ${ }^{4}$. Niezależnie od oceny wspomnianego podziału, pozwala on na sprawne przeniesienie prowadzonych tu rozważań na poziom praktycznej działalności logopedycznej: zadań, jakie stoją przed logopedą. Ich zakres okazuje się być bardzo szeroki, dotyczy działań związanych z terapią zaburzeń mowy, ale też ich profilaktyki.

Pedagogika twórczości jest bardzo młodą subdyscypliną pedagogiki. Jej przedmiot badań nie wydaje się budzić tak złożonych dyskusji jak w przypadku logopedii, choć oczywiście jest ujmowany w różny sposób przez przedstawicieli nauki, podobnie jak działy, które miałyby na nią się składać. Opierając się na znanym pedagogom twórczości "paradygmacie $4 \mathrm{P}^{\prime}$ Rossa Mooneya ${ }^{5}$, Krzysztof J. Szmidt opisuje ów przedmiot badań jako związany przede wszystkim ze złożonymi środowiskowymi uwarunkowaniami twórczości, począwszy od uwarunkowań kulturowych i społecznych, skończywszy na metodyce postępowania w procesie rozwijania zdolności twórczych. Do głównych działów pedagogiki twórczości zalicza teorie wychowania do twórczości oraz dydaktykę twórczości, a za zasadnicze zadanie omawianej subdyscypliny (a tym samym zada-

\footnotetext{
${ }^{4}$ G. Jastrzębowska, Podstawowe problemy logopedii, [w:] Logopedia. Pytania $i$ odpowiedzi..., s. 324-327.

${ }^{5} \mathrm{R}$. Mooney, A conceptual model for integrating four approaches to the identification of creative talent, [w:] Scientific creativity: Its recognition and development, red. C.W. Taylor, F. Barron, Wiley, New York 1963. 4P od słów: „product” (wytwór), "person” (osoba twórcza), "press” (rozumiane jako wpływ otoczenia), "process” (proces twórczy).
} 
nie stojące przed jej przedstawicielami) uznaje tzw. pomoc w tworzeniu dzieciom, młodzieży, osobom dorosłym. Składa się na nią inspirowanie, budzenie zdolności twórczych wychowanków, pomoc w niwelowaniu barier, które stoją na drodze ich działania twórczego oraz rozwijanie dyspozycji, zasobów, kompetencji, które potrzebne są $\mathrm{w}$ aktywności twórczej ${ }^{6}$. Inna polska badaczka pedagogiki twórczości, Janina Uszyńska-Jarmoc, określając przedmiot zainteresowań badawczych i działan praktycznych wspomnianej subdyscypliny, wskazuje na jej dwa działy: pedagogikę twórczości oraz pedagogikę kreatywności. Tę ostatnią traktuje jako dział praktyczny, zajmujący się sposobami rozwijania kreatywności i wyznaczający konkretne zadania pedagoga twórczościp. W szeroki zakres zadań pedagoga twórczości wpisuje się m.in. identyfikowanie, stymulowanie i wspieranie rozwoju zdolności twórczych, kreatywności dzieci, młodzieży i osób dorosłych.

Na poziomie przedmiotu badań i zainteresowań obu (sub)dyscyplin trudno więc wskazać wprost ich wspólne cele czy choćby obszary zainteresowań. Ale już na poziomie działania uprawianego przez praktyków staje się to możliwe. Logopedia stosowana - to właśnie na tym poziomie, a zatem na poziomie praktycznego działania logopedycznego możemy znaleźć obszary współpracy logopedii i pedagogiki twórczości. Będą one występować m.in. pod postacią łączenia celów związanych ze wspieraniem rozwoju mowy, terapią zaburzeń mowy, z celami związanymi ze stymulacją rozwoju kreatywności, potencjału twórczego podopiecznego. Możliwość działania twórczego dotyczyć będzie przede wszystkim dziecka, ale też samego logopedy i rodzica aktywnie uczestniczącego w procesie terapii logopedycznej. Nowe i wartościowe (a zatem twórcze) rozwiązania metodyczne autorstwa logopedy i rodzica, tworzenie au-

${ }^{6}$ K.J. Szmidt, Wśród aspektów, wymiarów, poziomów, biegunów, czyli o próbie konceptualizacji przedmiotów badań pedagogiki twórczości, [w:] Konceptualizacje przedmiotu badań pedagogiki, red. K. Rubacha, Oficyna Wydawnicza „Impuls”, Kraków 2008, s. 101-117.

${ }^{7}$ J. Uszyńska-Jarmoc, Twórcza aktywność dziecka. Teoria - rzeczywistość - perspektywy rozwoju, Trans Humana, Białystok 2003. 
torskich pomocy służących uatrakcyjnieniu, polepszaniu skuteczności prowadzonej praktyki, będą wpisywać się w tzw. twórczość pedagogiczną8. Nowatorska działalność na rzecz upowszechniania wiedzy logopedycznej i profilaktyki zaburzeń mowy może mieć także znamiona twórczości społecznej ${ }^{9}$. Podmioty aktywności twórczej i obszary tej aktywności podsumowane zostały $\mathrm{w}$ tabeli. $\mathrm{Z}$ uwagi na przyjętą tematykę niniejszego tekstu, informacje zawarte $\mathrm{w}$ tabeli ograniczają zakres praktyki logopedycznej do działalności dedykowanej dzieciom.

Tabela. Twórczość w praktyce logopedycznej

\begin{tabular}{|c|c|}
\hline \multicolumn{2}{|c|}{ Twórczość w praktyce logopedycznej } \\
\hline $\begin{array}{l}\text { Podmioty i rodzaje ich twórczej } \\
\text { aktywności w praktyce } \\
\text { logopedycznej }\end{array}$ & $\begin{array}{l}\text { Przykładowe działania twórcze } \\
\text { w praktyce logopedycznej }\end{array}$ \\
\hline $\begin{array}{l}\text { Twórczość pedagogiczna i społecz- } \\
\text { na logopedy }\end{array}$ & $\begin{array}{l}\text { Opracowywanie autorskich metod oraz na- } \\
\text { rzędzi diagnozy i pracy terapeutycznej; } \\
\text { opracowywanie autorskich pomocy/zabaw } \\
\text { służących w terapii i na zajęciach logope- } \\
\text { dycznych; } \\
\text { opracowywanie autorskich sposobów upo- } \\
\text { wszechniania wiedzy logopedycznej w celu } \\
\text { profilaktyki zaburzeń mowy }\end{array}$ \\
\hline Twórczość rodzica & $\begin{array}{l}\text { Opracowywanie autorskich pomocy wspie- } \\
\text { rających terapię logopedyczną dziecka; } \\
\text { opracowywanie autorskich pomocy/zabaw } \\
\text { wspierających rozwój mowy dziecka }\end{array}$ \\
\hline $\begin{array}{l}\text { Twórczość/kreatywność dziecka bio- } \\
\text { rącego udział w zajęciach logope- } \\
\text { dycznych/indywidualnej terapii lo- } \\
\text { gopedycznej }\end{array}$ & $\begin{array}{l}\text { Wykorzystywanie własnych zdolności twór- } \\
\text { czych, kreatywności, wyobraźni twórczej } \\
\text { podczas realizacji zadań w ramach indywi- } \\
\text { dualnej terapii logopedycznej/ grupowych } \\
\text { zajęć logopedycznych }\end{array}$ \\
\hline
\end{tabular}

Źródło: opracowanie własne

${ }^{8}$ R. Schulz, Twórczość pedagogiczna. Elementy teorii i badań, IBE, Warszawa 1994.

${ }_{9}^{9}$ R. Schulz, Twórczość - społeczne aspekty zjawiska, PWN, Warszawa 1990. 
To krótkie (z konieczności) wprowadzenie pokazuje oczywiste różnice między omawianymi dyscyplinami oraz niepodważalny status innych, niż stymulowanie kreatywności podopiecznego, celów praktyki logopedycznej. Pokazuje jednak także, jak dotąd na poziome teoretycznych rozważań, możliwości łączenia celów przyświecających pedagogowi twórczości i logopedzie, w ramach praktycznej działalności. Rozwijanie kreatywności podopiecznego nigdy nie będzie dla logopedy celem pierwszoplanowym. Może stać się jednak istotnym dodatkowym zadaniem, jakie przed sobą stawia.

Przed prezentacją praktycznych przykładów wspomnianych możliwości należy odpowiedzieć na pytanie zasadnicze: co mamy na myśli, mówiąc o kreatywności i zdolnościach twórczych? Jak słusznie zauważają bowiem Aleksander Nalaskowski10 i Robert Keith Sawyer ${ }^{11}$, trudno jest rozwijać twórczość/kreatywność, nie wiedząc, czym ona jest.

\section{Kreatywność jako cel działalności logopedy - wyjaśnienie podstawowych pojęć i założeń12}

Przyjmowane na użytek niniejszego tekstu rozumienie pojęcia kreatywności zakłada, iż jest to potencjat do generowania material-

10 A. Nalaskowski, Szkoła twórcza naprawdę i pozornie, [w:] Przeciwko edukacji sentymentalnej, A. Nalaskowski, Oficyna Wydawnicza „Impuls”, Kraków 1994, s. 63.

11 R.K. Sawyer, Explaining creativity. The science of human innovation, Oxford University Press, Oxford 2006, s. 295.

$12 \mathrm{~W}$ treści niniejszego artykułu znaleźć można dwa terminy, których związki są bardzo silne: twórczość i kreatywność. W wybranych miejscach artykułu terminy te zdają się być stosowane zamiennie, co sugerowałoby ich jednoznaczność. Zamienność ich stosowania wynika jednak z konotacji językowych, jakie mają w języku polskim, a także tradycji ich stosowania w ramach pedagogiki twórczości. Z tego właśnie powodu w przedstawianej tabeli posługuję się pojęciem „twórczości pedagogicznej”, a nie „kreatywności pedagogicznej”. To właśnie bowiem to pierwsze określenie ma już odpowiednie umocowanie $\mathrm{w}$ literaturze przedmiotu. Brak miejsca i zasadniczy temat niniejszego artykułu nie pozwalają na prowadzenie szczegółowych rozważań terminologicznych. Dość zaznaczyć, że w języku polskim terminy te bywają stosowane zamiennie, choć dyscyplina naukowa nie pozwala traktować ich całkowicie synonimicznie, co sygnalizuję w treści artykułu wyjaśniając znaczenie pojęcia „kreatywność”. 
nych (konkretne wytwory, prace dziecka) i/lub niematerialnych (pomysły, idee, zabawy...) produktów o charakterze twórczym. Potencjał ten jest związany ze sferą charakterologiczną oraz z poznawczymi kompetencjami tj. zdolnościami twórczymi ${ }^{13}$. W zakres sfery charakterologicznej wchodzą m.in. wrażliwość na problemy, otwartość i motywacja. Dyspozycje poznawcze istotne dla kreatywności (a także dla twórczości) określane mianem zdolności twórczych to: płynność, giętkość i oryginalność myślenia. Według przyjmowanego nadal wśród badaczy twórczości założenia Joya P. Guilforda, autora koncepcji tzw. myślenia dywergencyjnego ${ }^{14}$, do grupy zdolności poznawczych należy także wspomniana wcześniej wrażliwość na problemy.

Płynność myślenia rozumiana jest jako umiejętność wytwarzania wielu pomysłów, słów, skojarzeń. Mierzona jest ilością wytwarzanych rozwiązań. Jej cztery rodzaje to płynność: słowna (słowa generowane według przyjętego kryterium), ideacyjna (generowanie pomysłów), ekspresyjna i skojarzeniowa. Giętkość myślenia to zdolność wytwarzania jakościowo różnych wytworów, a oryginalność rozumiana jest jako umiejętność wychodzenia poza typowe rozwiązania15. Osoba wykorzystująca zdolności twórczego myślenia nie zadowala się pierwszym pomysłem, który przyjdzie jej do głowy w związku z rozwiązywanym problemem, potrafi wymyślać wiele różniących się do siebie jakościowo pomysłów, łączyć ze sobą na pozór odległe idee, obiekty, skojarzenia, aby wytworzyć nową jakość. Jej pomysły są jednocześnie oryginalne, wychodzą poza typowe skojarzenia związane $\mathrm{z}$ rozwiązywanym problemem. Aby w sytuacji zadaniowej dochodziło do takiego działania, potrzebne jest nie tylko wykorzystywanie własnych zdolności twórczych, ale i motywacja, by szukać dalej, nie poprzestawać na pierwszym rozwiązaniu, by działać wbrew pojawiającym się przeszkodom.

${ }^{13}$ M. Karwowski, Zgłębianie kreatywności. Studia nad pomiarem poziomu i stylu twórczości, Wydawnictwo APS, Warszawa 2008.

14 J. P. Guilford, Intelligence, creativity and their educational implications, Robert R. Kapp, San Diego 1968.

15 Ibidem; M.A. Runco, Divergent thinking. w: Encyclopedia of creativity, red. M.A. Runco, S. Pritzker, Academic Press, San Diego 1999, s. 577-582. 
Tak rozumiana kreatywność jest dostępna zarówno dorosłym, jak i dzieciom. W wyniku rozwoju, stymulacji, w połączeniu z wysokim poziomem uzdolnień i motywacji może przynieść w przyszłości efekty prawdziwie twórcze, mające wysoki walor nowości oraz wartość społeczną, wychodzącą poza znaczenie dla samego podmiotu. W przypadku dzieci mówimy o aktywności, która nawet jeśli nosi znamiona oryginalności i użyteczności (dwa podstawowe kryteria definiujące twórczość16), mają one wymiar bardziej osobisty niż społeczny, historyczny (np. dane działanie i jego efekty mają wartość rozwojową dla samego dziecka i są oryginalne w kontekście tego, co dziecko do tej pory zrobiło, ale już nie w rozumieniu szerokiej, społecznej wartości i oryginalności). Mówiąc o twórczości dziecka, najczęściej nie mamy na myśli dzieł wybitnych, zmieniających dziedzinę. Lokujemy ją raczej na niższych poziomach twórczości - twórczości płynnej (według podziału poziomów twórczości dokonanego przez Edwarda Nęckę ${ }^{17}$ ), Little c creativity (według Anny $\mathrm{Craft}^{18}$ ) czy mini c creativity (według terminologii Jamesa Kaufmanna i Ronalda Beghetto ${ }^{19}$ ). Dlatego to właśnie kreatywność wydaje się być w przypadku aktywności dziecka szczególnie trafnym terminem. Co jednak najważniejsze, tak rozumiana kreatywność oraz składające się na nią cechy charakterologiczne i dyspozycje poznawcze podlegają rozwojowi i wpływom edukacyjnym, na co wskazują lata badań naukowych i dokonań praktycznych prowadzonych przez psychologów i pedagogów twórczości ${ }^{20}$.

16 O definiowaniu twórczości i kreatywności oraz jej kryteriach podstawowych zob. więcej np. E. Nęcka, Psychologia twórczości, GWP, Sopot 2003; K.J. Szmidt, Pedagogika twórczości, GWP, Gdańsk 2013; M. Karwowski, op. cit.

17 E. Nęcka, Psychologia twórczości...

18 A. Craft, Little "c" creativity, [w:] Creativity in education, red. A. Craft, B. Jeffrey, M. Leibling, Continuum, London - New York 2001.

19 J.C. Kaufman, R.A. Beghetto, Beyond big and little: The four c model of creativity, "Review of General Psychology" 2009, nr 13(1), s. 1-12.

20 Por. np. E. Wiśniewska, M. Karwowski, Efektywność treningów twórczości - podejście metaanalityczne, "Ruch Pedagogiczny” 2007, nr. 3-4; E. Nęcka, Psychologia twórczości..., s. 199-209. 
Zaprezentowana tu $\mathrm{w}$ wielkim skrócie terminologia ma za zadanie wskazać zasadnicze założenie przyjmowane w niniejszych rozważaniach: kreatywność, zdolności twórcze, postrzegane jako potencjalny cel oddziaływań logopedy nie oznaczają kierowania aktywności dziecka w stronę działań artystycznych (co w przypadku praktyki logopedycznej byłoby trudne i nieuzasadnione), czy tych wymagających specjalnych uzdolnień. Przeciwnie, oznaczają stymulację i wspieranie rozwoju cech poznawczych i charakterologicznych posiadanych (nawet jeśli na różnym poziomie) przez każde dziecko i związanych z wieloma dziedzinami aktywności. Kreatywność dziecka może (nie musi) mieć miejsce podczas wykonywania pracy plastycznej, rysunku, ale też podczas wymyślania opowiadania, zabawy słownej, łączenia na pozór nie związanych ze sobą elementów (słów, skojarzeń, obiektów). To właśnie ta „wielodziedzinowość” kreatywności jest zasadniczą podstawą, dzięki której logopeda może traktować ją jako element własnej praktyki (włączać ją w tę praktykę).

\section{Metodyka pedagogiki twórczości w rękach logopedy: od zadania twórczego do twórczego zadania logopedycznego}

Omówione powyżej zdolności myślenia dywergencyjnego traktowane są przez pedagogów twórczości jako potencjał, którego rozwój należy wspierać. Do zasadniczych elementów metodyki pedagogiki twórczości zalicza się m.in. wszelkiego rodzaju zajęcia, treningi, na których realizowane są zadania angażujące wyżej wymienione zdolności. Bardzo często zajęcia takie oparte są o proces twórczego rozwiązywania autentycznych problemów grupy, z którą pedagog pracuje. Podczas ich rozwiązywania sięga on po cały arsenał metod i technik heurystycznych ${ }^{21}$, kieruje procesami gru-

${ }^{21}$ Zob. więcej np. K.J. Szmidt, Pedagogika twórczości..., s. 455-525; E. Nęcka, TRoP. Twórcze rozwiązywanie problemów, Oficyna Wydawnicza „Impuls”, Kraków 1994. 
powymi, odwołując się do psychodydaktycznych zasad prowadzenia zajęć twórczych ${ }^{22}$ oraz zasad treningu twórczości ${ }^{23}$, w celu stworzenia warunków sprzyjających generowaniu twórczych pomysłów. Pedagog podejmujący takie działania może skorzystać także z gotowych programów, które zarówno w Polsce, jak i za granicą stanowią inspirację do opracowywania własnych zajęć dla dzieci, młodzieży i osób dorosłych ${ }^{24}$. Dla logopedy pozycje te mogą stanowić źródło inspiracji, nie będą jednak znaczącym materiałem do wykorzystania na zajęciach logopedycznych, z uwagi na najważniejszy cel, który mu przyświeca: rozwój mowy podopiecznego. Logopeda jest więc specjalistą, który z naturalnych przyczyn nie będzie realizować wielu zadan typowych dla tzw. treningu twórczego myślenia. W swojej pracy kieruje się bowiem innymi celami, które traktuje priorytetowo. Zrozumienie istoty, charakterystyki zadań wykorzystywanych przez pedagogów twórczości pozawala jednak na łatwe zaadoptowanie ich do treści zadań logopedycznych.

Jak zaznaczono wcześniej, zadania stymulujące kreatywność, wyobraźnię twórczą, rozwijające zdolności twórczego myślenia mogą odwoływać się do szerokiego spektrum dziedzin i form aktywności, dawać okazję do zaangażowania w działanie o różnej treści i przynoszące różne efekty (materialne, niematerialne). A zatem dziedzina czy forma aktywności podmiotu nie jest wyznacznikiem dla cech zadania twórczego. Chodzi bardziej o istotę zadania niż o jego treść, formę czy rodzaj efektów, jakie przynosi. Swoiste

22 Zob. więcej w: M. Galewska-Kustra, Szkoła wspierająca twórczość uczniów. Teoria i przykład praktyki, Wydawnictwo Adam Marszałek, Toruń 2012, s. 98-103.

${ }^{23}$ Zob. więcej w: E. Nęcka, J. Orzechowski, A. Słabosz, B. Szymura, Trening twórczości, GWP, Gdańsk 2005.

24 Najbardziej znane polskie programy treningu twórczości i wychowania do twórczości dla dzieci to np. E. Nęcka, J. Orzechowski, A. Słabosz, B. Szymura, Trening twórczości, GWP, Gdańsk, 2005; K.J. Szmidt, Trening kreatywności. Podręcznik dla pedagogów, psychologów i trenerów grupowych, Helion, Gliwice, 2008; J. UszyńskaJarmoc, Podróże. Skarby. Przygoda. Podręcznik i program rozwijania twórczości, samoświadomości oraz dyspozycji autokreacyjnych dzieci klas I-III, Trans Humana, Białystok 2005. 
listy cech zadania twórczego budowane były przez wielu pedagogów. Znaczenie twórczego zadania jest bowiem na tyle istotnym elementem procesu wspierania rozwoju kreatywności, iż uwagę poświęca mu wielu psychologów i pedagogów twórczości. Polscy badacze, którzy zajmowali się tym zagadnieniem to m.in. Krzysztof J. Szmidt ${ }^{25}$ i Dorota Kubicka ${ }^{26}$. Najbardziej rozbudowana, szczegółowa lista cech zadania twórczego wskazana została przez tę ostatnią autorkę. Do zasadniczych cech zadania twórczego należy dywergencyjność, rozumiana jako otwartość. Zadanie twórcze pozwala na generowanie wielu możliwych rozwiązań, może przynosić różne efekty, nie polega na odszukaniu jednej poprawnej odpowiedzi. Do cech zadania pobudzającego myślenie twórcze i kreatywność, prócz wspomnianej dywergencyjności, Kubicka zalicza nowość, poznawczą dostępność (te cechy pozostają w oczywistej relacji z cechami podmiotu rozwiązującego zadanie), nieokreśloność, niepewność, dynamizm i złożoność, wzbudzanie ciekawości, podmiotową ważność, podmiotową kontrolę. Nieokreśloność oznacza niepełną strukturę zadania, przejawiającą się w braku części informacji go dotyczących, a także niepełnej wiedzy o sposobach postępowania w celu rozwiązania zadania, co stawia podmiot w sytuacji konieczności twórczego działania. Niepewność to cecha związana z pozostałymi właściwościami zadania twórczego. Aspekt nowości i nieokreśloności składa się na niepewność, jaką dziecko odczuwa w zetknięciu z sytuacją problemową o otwartym charakterze. Złożoność sytuacji polega na wielości czynników na nią się składających, natomiast dynamizm oznacza, iż w miarę działania w obrębie zadania otwartego jego struktura ulega zmianie. Zadanie twórcze to takie, które wzbudza ciekawość, motywację poznawczą. Zadanie może być więc ciekawe ze swojej natury albo skłaniać do poszukiwania nowych

${ }^{25}$ K.J. Szmidt, Wspótczesne koncepcje wychowania do kreatywności i nauczania twórczości: przegląd stanowisk polskich, [w:] Dydaktyka twórczości. Koncepcje - problemy rozwiązania, red. K.J. Szmidt, Oficyna Wydawnicza „Impuls”, Kraków 2003.

${ }^{26}$ D. Kubicka, Twórcze działanie dziecka w sytuacji zabawowo-zadaniowej, Wydawnictwo Uniwersytetu Jagiellońskiego, Kraków 2003. 
informacji w celu jego rozwiązania. Podmiotowa kontrola postulowana wobec zadań twórczych, odnosi się do możliwości wyboru działania, sposobu realizacji procesu rozwiązywania zadania, samodzielności postępowania - kontroli i oceny27. Warto także dodać, że istotnym czynnikiem wpływającym na aktywność twórczą i jej efekty jest także sposób formułowania polecenia kierowanego do dziecka. Badania wskazują m.in., że wyraźne zaznaczanie w poleceniu potrzeby oryginalności działania $\mathrm{w}$ istocie podnosi poziom oryginalności rozwiązań generowanych przez osoby rozwiązujące zadanie ${ }^{28}$.

Ta z konieczności krótka charakterystyka zadania twórczego ${ }^{29}$ pokazuje możliwości i ograniczenia w jego stosowaniu w praktyce logopedycznej. Jest ono często bardzo złożone, na jego wykonanie potrzeba więc czasu, a ten w terapii logopedycznej poświęcany jest na cele priorytetowe, związane z mową podopiecznego. Jednocześnie cechy te mogą być realizowane w zadaniach o różnym poziomie trudności i złożoności. Każdy logopeda będzie potrafił wykorzystać je w zadaniu przedstawianemu dziecku tak, by z jednej strony wspierało kreatywność, a $\mathrm{z}$ drugiej pomagało $\mathrm{w}$ realizacji zasadniczych celów logopedycznego działania i było adekwatne do możliwości oraz potrzeb rozwojowych podopiecznego. Cechy te są na tyle „uniwersalne”, iż niewielkim wysiłkiem dadzą się włączyć w szereg zadań o charakterze logopedycznym. Rozumiejąc ich zasadniczy sens, kreatywny logopeda z łatwością opracuje zadanie tak, by dawało możliwość twórczego działania, a jednocześnie w zależności od celu pracy z danym dzieckiem - np. wspomagało utrwalanie poprawnej artykulacji ćwiczonej głoski, odnosiło się do ćwiczonego materiału językowego, stymulowało budowanie złożonej wypowiedzi itp.

27 Ibidem.

${ }^{28}$ M.A. Runco, Creativity. Theories and themes: research, development, and practice, Elsevier Academic Press, Amsterdam, Boston, Heidelberg, London, New York, Oxford, Paris, San Diego, San Francisco, Singapore, Sydney, Tokyo 2007.

${ }^{29}$ Zob. więcej: M. Galewska-Kustra, Szkoła wspierająca twórczość uczniów. Teoria i przykład praktyki, Wydawnictwo Adam Marszałek, Torun 2012, s. 98-103. 


\section{Logopeda jako pedagog twórczości - przykłady twórczych zadań logopedycznych ${ }^{30}$}

Cele działalności logopedycznej są zależne od potrzeb i możliwości rozwojowych osób, wobec których są kierowane. Forma i treść twórczego zadania logopedycznego będą więc także nimi warunkowane. Materiał językowy (np. zasób wyrazowy, głoskowy, fleksja, określona budowa zdania itd.), który w danym przypadku jest realizowany, ale też możliwości poznawcze, a nawet motoryczne dziecka, określać będą wspomniane elementy zadania proponowanego podopiecznemu. Prezentowane poniżej przykłady zadań dotyczą różnych możliwości i potrzeb dziecka, a także różnych celów terapii logopedycznej czy logopedycznych zajęć grupowych.

Przykład 1.

Cele logopedyczne: ćwiczenie umiejętności budowania wypowiedzi złożonej, opowiadania, ćwiczenie/utrwalanie poprawnej artykulacji.

Cele z zakresu pedagogiki twórczości: stymulowanie kreatywności, wyobraźni twórczej dziecka.

Potrzebne materiały: dwie strony z książki Twórcze bazgroły. Przygody Ważki Grażki31, kredki lub wycięte papierowe obiekty (w zależności od zakładanych celów logopedycznych), klej.

${ }^{30}$ Posługując się w niniejszym artykule terminem „twórcze zadanie logopedyczne", mam na myśli takie zadanie, które z jednej strony realizuje cele dotycząc rozwoju mowy dziecka, a z drugiej stymuluje jego kreatywność, skłania do wykorzystywania zdolności twórczych, uruchamia wyobraźnię twórczą.

${ }^{31}$ D. Dziedziewicz, A. Gajda, E. Karwowska, Twórcze bazgroły. Przygody ważki Grażki, Harmonia, Warszawa 2011, s. 67-68. Książka typu doodle book (pol. bazgroszyt), która zachęca dziecko do wykorzystania własnej wyobraźni twórczej w celu przekształcenia, dokończenia rozpoczętej historii zaprezentowanej poprzez elementy graficzne zaprezentowane na obrazku. W przypadku tej publikacji wstępem do pracy z obrazkiem jest także wysłuchanie krótkiego wiersza, który wprowadza $\mathrm{w}$ zaprezentowany początek historii. 
Po wysłuchaniu wiersza głównym bohaterze zadania: potworku, którego boli brzuch, ponieważ najadł się czegoś niestrawnego, zadaniem dziecka jest wymyślić i narysować jak najwięcej (płynność myślenia) różnych (giętkość myślenia) obiektów, które ten mógł zjeść. Zadanie można przekształcić na potrzeby np. ćwiczenia poprawnej artykulacji, różnicowania głosek, słuchu fonemowego. Wystarczy określić jaką głoskę w nazwie powinny zawierać wymyślane przez dziecko obiekty albo przygotować materiał obrazowo-wyrazowy zawierający te głoski. W tym ostatnim przypadku dziecko wybiera odpowiednie jego zdaniem obiekty, układa ja na obrazku i nazwa, a następnie opowiada co i dlaczego zjadł bohater historii. Efektem pracy dziecka jest więc rysunek lub obrazek ułożony z wyciętych elementów. Dla logopedy najważniejszym jednak efektem będzie wypowiedź dziecka. W zależności od celów terapii logopedycznej może ona przyjąć różną postać: pojedynczych zdań lub złożonej opowieści budowanej przez dziecko, czy wypowiedzi zawierającej określony materiał artykulacyjny. Jeśli dziecko ma trudności z budowaniem złożonej wypowiedzi, zapisujemy na karteczkach pojedyncze zdania, którymi opisuje sytuację na rysunku, a następnie wspólnie odczytujemy wszystkie zdania, budując tym samym dłuższą wypowiedź.

Przykład 2.

Cele logopedyczne: utrwalanie poprawnej wymowy głoski [r], rozwijanie umiejętności budowania złożonej wypowiedzi.

Cele z zakresu pedagogiki twórczości: rozwijanie kreatywności i wyobraźni twórczej dziecka, ćwiczenie umiejętności odległego kojarzenia.

Potrzebne materiały: dwie strony z książki Zeszytowy trening mowy, czyli ćwiczenia logopedyczne dla dzieci32, kredki.

Zadanie polega na wymyśleniu wizerunku oraz zwyczajów nieistniejącego zwierzęcia. Punktem wyjścia do zadania jest opowieść

32 M. Galewska-Kustra, Zeszytowy trening mowy, czyli ćwiczenia logopedyczne dla dzieci, Nasza Księgarnia, Warszawa 2015, s. 50-51. 
o naukowcu, który odkrył nieznane dotąd zwierzęta, ale zdradził jedynie nadane im nazwy (m.in. Trampkowiec Malutki, Dropsojad, Gryzoń Marudny). Dziecko rysuje wizerunek zwierzęcia, decydując jednocześnie, które z obiektów dodatkowych pokazanych na kartach pracy (m.in. drabina, parasol, grabie...) są zwierzęciu przydatne i do czego. Po zakończeniu pracy dziecko opowiada o wymyślonym przez siebie zwierzęciu. Dzięki zastosowanym nazwom zwierząt i obiektów dodatkowych, dziecko ma wielokrotną okazję do artykulacji ćwiczonej głoski.

Przykład 3.

Cele logopedyczne: rozwijanie umiejętności budowania złożonej wypowiedzi, utrwalanie poprawnej artykulacji, ćwiczenie zastosowania wyrażeń przyimkowych (w zależności od potrzeb danego dziecka).

Cele z zakresu pedagogiki twórczości: ćwiczenie umiejętności dokonywania twórczych skojarzeń, rozwijanie wyobraźni twórczej i kreatywności dziecka.

Potrzebne materiały: plansza z narysowanym tłem dla historii, figurki lub wycięte płaskie obrazki z wizerunkami różnorodnych obiektów i postaci (w zależności od tematyki samej planszy oraz aktualnych potrzeb logopedycznych).

Logopeda przygotowuje planszę z narysowanym tłem dla historii, którą będzie tworzyć razem z dzieckiem. Elementy tła są zależne od pomysłowości logopedy i aktualnego zapotrzebowania wynikającego z celów terapii logopedycznej (np. ulica, wieś, las, kosmos, dom itd.). Do zabawy potrzebne są także ruchome obiekty (figurki lub wycięte z papieru płaskie wizerunki różnych obiektów, postaci). Jeśli celem terapii logopedycznej jest ćwiczenie poprawnej artykulacji, nazwy ruchomych obiektów i elementów tła powinny zawierać ćwiczone głoski. Ruchome elementy są losowane raz przez dziecko, raz przez logopedę. Po wylosowaniu obiektu należy znaleźć dla niego zastosowanie w tworzonej historii (zbudować wypowiedź, w której się pojawi i która będzie adekwatna do tematyki planszy) oraz umieścić go na planszy. Kolejna osoba losuje następny przed- 
miot i kontynuuje historię. W przypadku logopedycznych zajęć grupowych, obiekty będą losowane kolejno przez każde dziecko.

Przykład 4.

Cele logopedyczne: rozwijanie umiejętności budowania złożonej wypowiedzi, ćwiczenie sprawności narządów artykulacyjnych.

Cele z zakresu pedagogiki twórczości: rozwijanie kreatywności, zdolności twórczych, wyobraźni twórczej dziecka.

Potrzebne materiały: Książka Z mucha na luzie ćwiczymy buzie, czyli zabawy logopedyczne dla dzieci33, wycięte obrazki z wizerunkami bohaterki historii (różne emocje) i różnorodnych obiektów (wybór dowolny, podyktowany potrzebami logopedycznymi).

Dziecko wysłuchuje kilku przygód muchy, bohaterki książki, i wykonuje ćwiczenia sprawności narządów artykulacyjnych w niej zawarte. Kolejnym zadaniem dziecka jest wymyślenie nowej przygody małej muchy. W zależności od możliwości dziecka, logopeda może pozostawić dziecku całkowitą dowolność albo przygotować materiał, który będzie pomocny w tym procesie (np. wycięte obrazki obiektów, wizerunków muchy z różnymi emocjami itp.). Dziecko wybiera obrazki wedle własnego uznania (trudniejsza wersja: obrazki są wybierane losowo) i na ich podstawie opowiada nową przygodę bohaterki książki. Odczytane przygody muchy można także wykorzystać do ćwiczenia umiejętności transformowania i wyobraźni twórczej, dokonując prób przekształcania poznanej historii. W tym celu logopeda może zadać dziecku szereg pytań, typu: „Co by było gdyby?”, które będą wspomagać generowanie nowych rozwiązań.

Przykład 5.

Cele logopedyczne: rozwijanie umiejętności budowania złożonej wypowiedzi, utrwalanie poprawnej artykulacji głoski [š].

${ }_{33}$ M. Galewska-Kustra, Z muchą na luzie ćwiczymy buzie, czyli zabawy logopedyczne dla dzieci, Nasza Księgarnia, Warszawa 2015. 
Cele z zakresu pedagogiki twórczości: rozwijanie kreatywności, zdolności twórczych, wyobraźni twórczej dziecka.

Potrzebne materiały: dwie strony z książki Zeszytowy trening mowy, czyli ćwiczenia logopedyczne dla dzieci34, kredki.

Dziecko nazywa obiekty znajdujące się w mysiej norce (ilustracja z książki) oraz nazywa jej mieszkańców (nazywane obiekty oraz imiona zwierząt zawarte na ilustracji zawierają ćwiczoną głoskę). Kolejnym zadaniem dziecka jest wymyślenie i narysowanie dodatkowych przedmiotów, które przydałyby się bohaterkom historii $\mathrm{w}$ ich mieszkaniu oraz uzasadnienie swoich wyborów.

\section{Zakończenie}

Przedstawione $\mathrm{w}$ niniejszym artykule przykłady zadań są celowo proste pod względem formy i zastosowanych materiałów. Znajdą one zastosowanie $w$ terapii logopedycznej, dając jednocześnie szansę na rozwijanie kreatywności podopiecznego. Przykłady te mają $\mathrm{w}$ zamyśle pokazać, że rozwijanie kreatywności dziecka $\mathrm{w}$ trakcie terapii logopedycznej jest nie tylko zadaniem możliwym, ale i nie trudnym $\mathrm{w}$ realizacji. Myślenie o zadaniu proponowanym dziecku w trakcie zajęć logopedycznych jako o stymulującym jego szeroko rozumiany rozwój, może przynieść co najmniej dwojakie korzyści: stymulować ten rozwój oraz motywować dziecko je do zaangażowanego, autentycznego uczestnictwa $\mathrm{w}$ terapii.

To właśnie perspektywa praktyczna, konkretne współdziałanie z dzieckiem w trakcie zajęć logopedycznych, daje nam sposobność dostrzeżenia związków logopedii z pedagogiką twórczości: (sub)dyscyplin, których przedmioty badań i zainteresowań są od siebie tak odległe. Nawet jeśli rozwijanie kreatywności podopiecznego nie będzie nigdy celem zasadniczym działania logopedy, może stać się

${ }^{34}$ M. Galewska-Kustra, Zeszytowy trening mowy..., Nasza Księgarnia, Warszawa 2015, s. 40-41. 
istotnym elementem pracy $\mathrm{z}$ dzieckiem, które wzbogaca jego aktywność, przynosi dodatkowe efekty terapii, a także stawia nowe wyzwania zawodowe przed samym logopedą.

\section{Bibliografia}

Craft A., Little "c" creativity. w: Creativity in education, red. A. Craft, B. Jeffrey, M. Leibling, Continuum, London - New York 2001.

Dziedziewicz D., Gajda A., Karwowska E., Twórcze bazgroły. Przygody ważki Grażki, Harmonia, Warszawa 2011.

Galewska-Kustra M., Szkoła wspierająca twórczość uczniów. Teoria i przykład praktyki, Wydawnictwo Adam Marszałek, Torun 2012.

Galewska-Kustra M., Z muchą na luzie ćwiczymy buzie, czyli zabawy logopedyczne dla dzieci, Nasza Księgarnia, Warszawa 2015.

Galewska-Kustra M., Zeszytowy trening mowy, czyli ćwiczenia logopedyczne dla dzieci, Nasza Księgarnia, Warszawa 2015.

Grabias S., Mowa i jej zaburzenia, „Audiofonologia” 1997, t. 10.

Guilford J. P., Intelligence, creativity and their educational implications, Robert R. Kapp, San Diego 1968.

Jastrzębowska G., Podstawowe problemy logopedii, [w:] Logopedia. Pytania i odpowiedzi. Tom 1: Interdyscyplinarne podstawy logopedii, red. T. Gałkowski, G. Jastrzębowska, Wydawnictwo Uniwersytetu Opolskiego, Opole 2003.

Kaczmarek L., Model opieki logopedycznej w Polsce, Gdański Związek Logopedów, Gdańsk 1991.

Karwowski M., Zgłębianie kreatywności. Studia nad pomiarem poziomu i stylu twórczości, Wydawnictwo APS, Warszawa 2008.

Kaufman J.C., Beghetto R.A., Beyond big and little: The four c model of creativity, "Review of General Psychology" 2009, nr 13(1).

Kubicka D., Twórcze działanie dziecka w sytuacji zabawowo-zadaniowej, Wydawnictwo Uniwersytetu Jagiellońskiego, Kraków 2003.

Mooney R., A conceptual model for integrating four approaches to the identification of creative talent, [w:] Scientific creativity: Its recognition and development, red. C.W. Taylor, F. Barron, Wiley, New York 1963.

Nalaskowski A., Szkoła twórcza naprawdę i pozornie, [w:] Przeciwko edukacji sentymentalnej, A. Nalaskowski, Oficyna Wydawnicza „Impuls”, Kraków 1994.

Nęcka E., Orzechowski J., Słabosz A., Szymura B., Trening twórczości, GWP, Gdańsk 2005.

Nęcka E., Psychologia twórczości, GWP, Sopot 2003. 
Nęcka E., TRoP. Twórcze rozwiąywanie problemów, Oficyna Wydawnicza „Impuls”, Kraków 1994.

Runco M.A., Creativity. Theories and themes: research, development, and practice, Elsevier Academic Press, Amsterdam, Boston, Heidelberg, London, New York, Oxford, Paris, San Diego, San Francisco, Singapore, Sydney, Tokyo 2007.

Runco M.A., Divergent thinking, [w:] Encyclopedia of creativity, red. M.A., Runco, S. Pritzker, Academic Press, San Diego 1999.

Sawyer R.K., Explaining creativity. The science of human innovation, Oxford University Press, Oxford 2006.

Schulz R., Twórczość - społeczne aspekty zjawiska, PWN, Warszawa 1990.

Schulz R., Twórczość pedagogiczna. Elementy teorii i badań, IBE, Warszawa 1994.

Szmidt K.J., Pedagogika twórczości, GWP, Gdańsk 2013.

Szmidt K.J., Wspótczesne koncepcje wychowania do kreatywności i nauczania twórczości: przeglad stanowisk polskich, [w:] Dydaktyka twórczości. Koncepcje - problemy - rozwiązania, red. K.J. Szmidt, Oficyna Wydawnicza „Impuls”, Kraków 2003.

Szmidt K.J., Trening kreatywności. Podręcznik dla pedagogów, psychologów i trenerów grupowych, Helion, Gliwice 2008.

Szmidt K.J., Wśród aspektów, wymiarów, poziomów, biegunów, czyli o próbie konceptualizacji przedmiotów badań pedagogiki twórczości, [w:] Konceptualizacje przedmiotu badań pedagogiki. red. K. Rubacha, Oficyna Wydawnicza „Impuls”, Kraków 2008.

Uszyńska-Jarmoc J., Podróże. Skarby. Przygoda. Podręcznik i program rozwijania twórczości, samoświadomości oraz dyspozycji autokreacyjnych dzieci klas I-III, Trans Humana, Białystok 2005.

Uszyńska-Jarmoc J., Twórcza aktywność dziecka. Teoria - rzeczywistość - perspektywy rozwoju, Trans Humana, Białystok 2003.

Wiśniewska E., Karwowski M., Efektywność treningów twórczości - podejście metaanalityczne, „Ruch Pedagogiczny” 2007, nr 3-4. 